COMU J Mar Sci Fish

2020 3(2): 79-94

DOI: $10.46384 /$ jmsf.794153

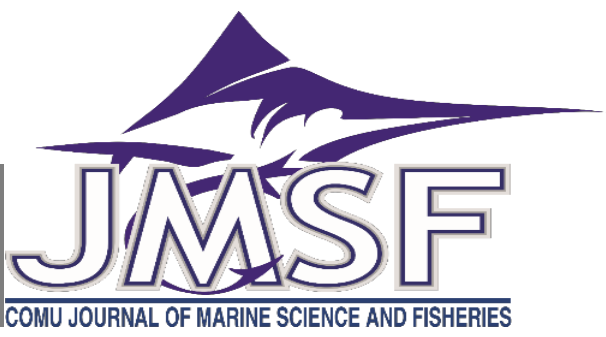

e-ISSN 2651-5326

\title{
Acoustic Estimates of Leaf Height and Biomass of Posidonia oceanica Meadow in Gulf of Antalya, the Eastern Mediterranean
}

\author{
Cansu Olguner ${ }^{1}$, Erhan Mutlu ${ }^{2 *}$ \\ ${ }^{1}$ Bahçeşehir High School, Antalya, Turkey \\ ${ }^{2}$ Akdeniz University, Faculty of Fisheries, Dumlupınar Boulevard, 07058, Campus Antalya \\ Correspondent: erhmut@akdeniz.edu.tr \\ Erhan Mutlu: Orcid 0000-0002-6825-3587
}

How to cite this article: Olguner, C. \& Mutlu, E., (2020). Acoustic estimates of leaf height and biomass of Posidonia oceanica meadow in Gulf of Antalya, the eastern Mediterranean. COMU J. Mar. Sci. Fish, 3(2): 79-94. DOI: 10.46384/jmsf.794153

\begin{abstract}
Vegetation cover on the sea floor plays an important role in marine health, and sonar systems can provide detailed observation and evaluation of sea floor vegetation under rapidly changing environmental conditions. Various acoustic techniques are available for this purpose. In this study, a split beam echo sounder operating at a frequency of $206 \mathrm{kHz}$ was employed. Simultaneous dive expeditions were performed for direct acoustic observations. The aim of this study was to use the BioSonics EcoSAV software program to generate acoustic estimates of leaf height and create seasonal distribution maps in Posidonia oceanica meadows distributed between Lara and Manavgat in the Gulf of Antalya (Turkey). Calculation of program parameters by species and acoustic identification of $P$. oceanica were carried out with the aid of the PAST 3.05 (PAleontological STatistics) statistics program, enabling isolation of P. oceanica and other non-target species from the sea floor. The results revealed three major meadow beds in the study area. The maximum leaf height was observed in July $(80-90 \mathrm{~cm})$, followed by April/May $(70-80 \mathrm{~cm})$, with the shortest leaf height in January $(40-50 \mathrm{~cm})$. The biomass of the leaves varied seasonally between 100 and $1000 \mathrm{~g} / \mathrm{m}^{2}$ and decreased by the seafloor depth in a year. This method proved effective for mapping and monitoring important seasonal habitat parameters such as the distribution of aquatic vegetation.
\end{abstract}

Keywords: Acoustic Identification, Meadow, Leaf Height, Biomass, Temporal and Spatial Distribution

\section{Antalya Körfezi’ndeki Posidonia oceanica Deniz Çayırının Yaprak Boyu ve Biyokütle Miktarının Akustiksel Tahminleri}

Özet: Deniz tabanındaki bitkiler deniz sağlı̆̆ının göstergesi olarak önemli bir rol oynarlar ve sonar sistemleri çevre koşuların ani değişimleri durumundadeniz tabanı bitki örtüsünün ayrıntılı gözlem ve değerlendirmesini sağlayabilir. Bu tür çalışmalar için değişik akustik teknikler mevcuttur. Bu çalışmada, $206 \mathrm{kHz}$ frekanslı split beam ekosounder kullanılmıştır. Akustik çalışma esnasında, eşzamanlı dalış seferleri de yapılmıştır. Bu çalışmanın amacı BioSonics EcoSAV ticari yazılımı kullanarak Antalya Körfezi'nin (Türkiye) Lara-Manavgat arasındaki bölgede bulunan Posidonia oceanica yaprak boyu tahmini yapmak ve mevsimsel dağılım haritasını çıkartmaktır. Program parametrelerinin hesaplanması ve deniz tabanındaki hedef olmayan diğer türlerden $P$. oceanica'nın ayrılabilmesi ve $P$. oceanica çayırının akustik olarak tanımlanmasında PAST 3.05 (PAleontological STatistics) istatistik programı, kullanılmıştır. Sonuçta, çalışma alanında 3 büyük deniz çayırı yatağının var olduğu tespit edilmiştir. En yüksek yaprak boyu Temmuz ayında ve 80-90 cm olarak, daha kısa yaprak boyu ise Nisan/Mayıs aylarında $(70-80 \mathrm{~cm})$ en kısa yaprak boyu ise Ocak ayında $(40-50 \mathrm{~cm})$ ölçülmüştür. Yaprak biyokütlesi mevsimsel olarak 100 ve $1000 \mathrm{~g} / \mathrm{m}^{2}$ arasında değişmiştir ve deniz tabanı derinliği ile azalmıştır. Bu metodun, sucul bitkilerin dağılımı gibi mevsimsel habitat parametrelerinin haritalanması ve izlenmesinde etkili olduğu ortaya konulmuştur.

Anahtar Kelimeler: Akustik Tanımlama, Deniz Çayırı, Yaprak Boyu, Biyokütle, Alansal ve Zamansal Dağılım. 


\section{Introduction}

Seagrass ecosystems have a very wide geographical distribution, from tropical to coldtemperate areas and play important ecological, geological, biological, and economic functions within the coastal ecosystem (Spalding et al., 2003). In this regard, they are among the most valuable ecosystems in the world (Spalding et al., 2003; Foden and Brazier, 2007). Posidonia oceanica is an endemic Mediterranean seagrass that forms rich and broad meadows up to $40-50 \mathrm{~m}$ along the Mediterranean coast. It has been defined as a "good bioindicator organism" of marine health because of its propensity to thrive in clean water habitats only (Augier, 1985; Pergent-Martini and Pergent, 2000; Bhattacharya et al., 2003; Foden and Brazier, 2007). However, as a result of multiple stresses, there has been a significant decline in $P$. oceanica meadows throughout the entire Mediterranean basin (Boudouresque et al., 2009; Montefalcone, 2009; Marín-Guirao et al., 2013; Telesca et al., 2014). Consequently, P. oceanica is a protected species in various marine protected areas in countries along the Mediterranean Sea (UNEP-MAPRAC/SPA 2009). P. oceanica is included in the Barcelona Convention Annex II (list of endangered or threatened species), as indicated by The International Union for Conservation of Nature (IUCN, 2017). Furthermore, the species is included in Annex I (Strictly Protected Flora Species) of the Convention on the Conservation of European Wildlife and Natural Habitats (Bern Convention). In Turkey, $P$. oceanica meadows are also protected as per the "Circular on Sea and Inland Waters $n^{\circ} 37 / 1$ " (UNEP-MAP-RAC/SPA 2007), which applies to regulations relevant to fishing, as imposed by the Ministry of Agriculture.

Some researchers (Marbà et al., 2014; Holon et al., 2015) have estimated the rate of temporal change on bed size of $P$. oceanica meadows over more than 50 years on some coasts of the Mediterranean basin. However, the data remain insufficient. For this reason, environmental mapping and monitoring are important to understand both the current state of coastal habitats and temporal changes in these areas. In addition, detailed spatial and morphometric information relating to habitat is a prerequisite for the sustainable management of marine coastal areas. It is particularly necessary to develop a regional strategy for monitoring coastal and marine habitats, such as regional monitoring plans for specific habitat types. Seagrass meadows are a key habitat in sustainable conservation and coastal management studies.

The detection of vegetation cover and distribution is particularly important, but previous studies have only employed standard methods (observations, sampling or marking with SCUBA, photography with the quadrat technique, satellite) (Pergent-Martini et al., 2005b; Yücel-Gier et al., 2020). Recently, acoustic devices (i.e., side-scan sonar, multi-beam echo sounder) and remote-controlled vehicles have been used for highly effective seabed mapping and characterization (Bonacorsi et al., 2013; Montefalcone et al., 2013; Buchet, 2015; Duman et al., 2019). Acoustic methods are more advantageous than standard methods because they are easier to apply and can be employed quickly over large areas without involving a large team. In addition, on-site observation, visual census, and visual monitoring are laborious and time consuming. In contrast, demands on human effort and time are reduced when using remote sensing systems (Komatsu et al., 2003; Buchet, 2015; Yücel-Gier et al., 2020). There is a need for new, fast, cost-effective, and approved strategies and methods to monitor and protect existing changes in susceptible species, especially those with a tendency to decline rapidly, such as $P$. oceanica. In addition to these systems, the development of Geographic Information System (GIS) software makes it possible to obtain real-time, detailed, and geographically referenced distribution maps and data. Over the past few years, the development of various specialized commercial software for seafloor classification and bottom identification has enabled more efficient use of acoustic techniques for mapping large macrophytes. Despite this, vegetation and acoustic reflection characteristics remain poorly understood. For this reason, commonly used methods are often combined to obtain more detailed information. For instance, SCUBA diving can be performed to verify acoustic recordings in situ (sea-truth experiments) (SánchezCarnero et al. 2012; Mutlu et al. 2014; Mutlu and Balaban, 2018), or data can be controlled by combining other instruments (side scan, Multi-beam Side Scan, MBS) with the acoustic system (Pasqualini et al., 1998, Di Maida et al. 2011).

The EcoSAV (Eco Submerged Aquatic Vegetation) program has been used to successfully identify plant communities in many different regions (McCarthy and Sabol, 2000; Schneider et al., 2001; Sabol et al., 2002; Sabol et al., 2009). Although the use of EcoSAV commercial software with high frequencies is more effective for identifying seagrasses (Valley et al., 2005; Farrel et al., 2013), lower frequencies between 200 and $400 \mathrm{kHz}$ are potentially optimal for the identification of macrophytes (Elliott et al., 1996; George and Winfield, 2000; Wanzenböck et al., 2003; Schmidt et al., 2005; Winfield et al., 2007; Mutlu et al., 2014).

Monitoring of marine meadows is required to evaluate the effectiveness of conservation and coastal management measures. Therefore, it is important to accurately determine coverage (Prado et al., 2010) and distribution areas. It is also vital to implement standardized monitoring methods in order to compare results across the Mediterranean basin and protect vulnerable marine meadows (Pergent-Martini et al., 2005a). Although $P$. oceanica is one of the most 
important and well-studied Mediterranean species, only a limited number of studies have attempted to synthesize the available spatial information, and determine the current distribution and total area of $P$. oceanica seagrass beds (Giakoumi et al., 2013). Furthermore, these studies involved either scattered numerical data, a limited spatial range, or very low spatial resolution of data. In addition, such data sets are not available online, with some rare exceptions.

In this study, we aim to produce a seasonal map of leaf height distribution for $P$. oceanica meadows around Antalya Gulf, Turkey. We used BioSonics EcoSAV® and VBT Seabed Classifier commercial software programs in order to: 1) perform acoustic identification of $P$. oceanica species, and 2) calibrate relevant parameters within the algorithm to provide this definition and leaf length and biomass. In this way, both EcoSAV and VBT were calibrated. This study takes advantage of acoustic systems to identify $P$. oceanica meadows according to their acoustic properties, and uses the EcoSAV program, which is calibrated to define the acoustic backscatter characteristics of $P$. oceanica meadows on the sea floor.

\section{Material and Methods}

The study area is in the Gulf of Antalya (Turkey, Eastern Mediterranean), between Lara and Manavgat

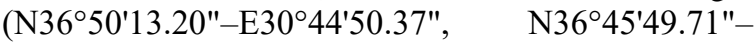
E31 $\left.{ }^{\circ} 23^{\prime} 2.33^{\prime \prime}\right)$ (Figure 1). The study area was chosen because $P$. oceanica meadows are dense and the sea floor shows no sudden changes in depth. We also considered the most effective working environment in terms of ship traffic and fishing activity (i.e., close to the harbor). The site constitutes a pilot region for monitoring seagrass meadows in the future. The study was conducted in six different months between 2 July 2011 and 31 August 2012 (July 2011, November/December 2011, January 2012, March 2012, April/May 2012, and August 2012). In order to determine the distribution of $P$. oceanica, a field selection was made considering the gentle slope in the Gulf of Antalya. The research was carried out between Antalya (Lara) and Manavgat, reaching a maximum depth of $70 \mathrm{~m}$. The total coastal length was 35 NM.

Data were collected using a BioSonics DX 206 $\mathrm{kHz}$ (source level $220.4 \mathrm{~dB}$ re $1 \mu \mathrm{Pa}$ at $1 \mathrm{~m}$ ), $6.8^{\circ}$ split-beam echo sounder set to $0.1 \mathrm{~ms}$ pulse-width, 5 pings $\mathrm{s}^{-1}$, and a threshold of $-140 \mathrm{~dB}$.

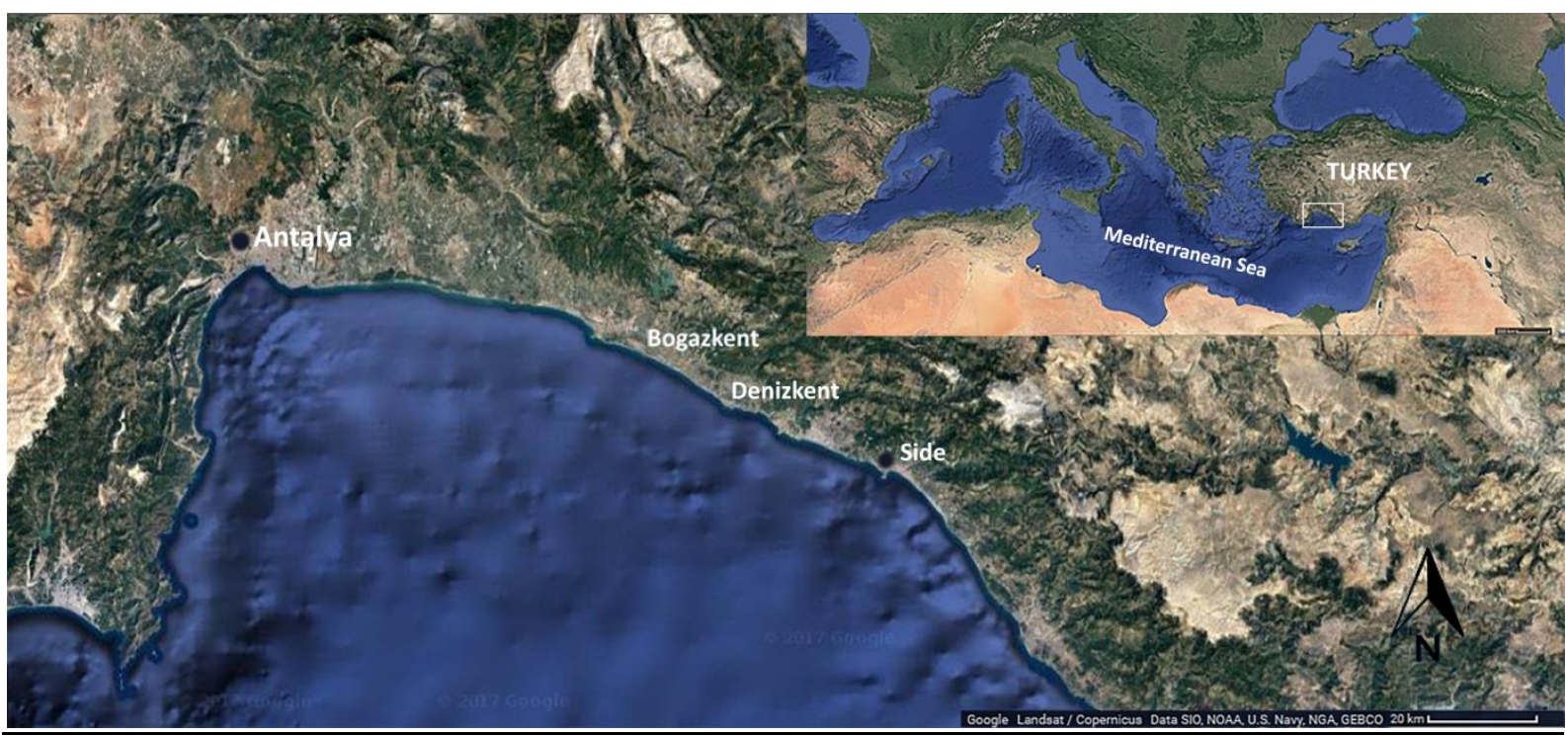

Figure 1. Location of the Antalya Bay study area in the Mediterranean Sea.

The transducer was mounted on the sides of $\mathrm{R} / \mathrm{V}$ Akdeniz $S u$, and the array faces were orientated vertically downwards. It was mounted in a specially designed housing around the transducer to remove the effect of foam from the cruiser. Data were collected at a boat speed of $5.0-6.0 \mathrm{~km} \mathrm{hr}^{-1}$. The points and lines of the study were optimized by considering the density, depth of the patchy distribution, size of bed areas according to the species, and depth of the seagrass (Figure 2).
A total of 228 acoustic lines were scanned over a month. According to the size and variation of meadows, lines were arranged at intervals of 0.25 $\mathrm{NM}$ between depths of 5 and $70 \mathrm{~m}$, shown by the red lines in Figure 2. In addition, for seasonal samples, each working line was shifted $80 \mathrm{~m}$ to the east. The frequent sampling interval throughout the study area allowed each spot to be scanned in fine detail. Scuba dive transcriptions were made in the field to verify the validity of the acoustic records. 
Dives were performed at 14 locations for in-situ verification. The standard dive depths were $5 \mathrm{~m}, 10$ repetitions at each depth. At the calibration locations, $1 \times 1 \mathrm{~m}$ quadrats were used, and samples were $\mathrm{m}, 15 \mathrm{~m}, 20 \mathrm{~m}$, and $30 \mathrm{~m}$. Random sampling was performed with quadrats of $40 \times 40 \mathrm{~cm}$ with three collected by dilution in six sections (green-framed area in Figure 2). The total line length was 400 NM.

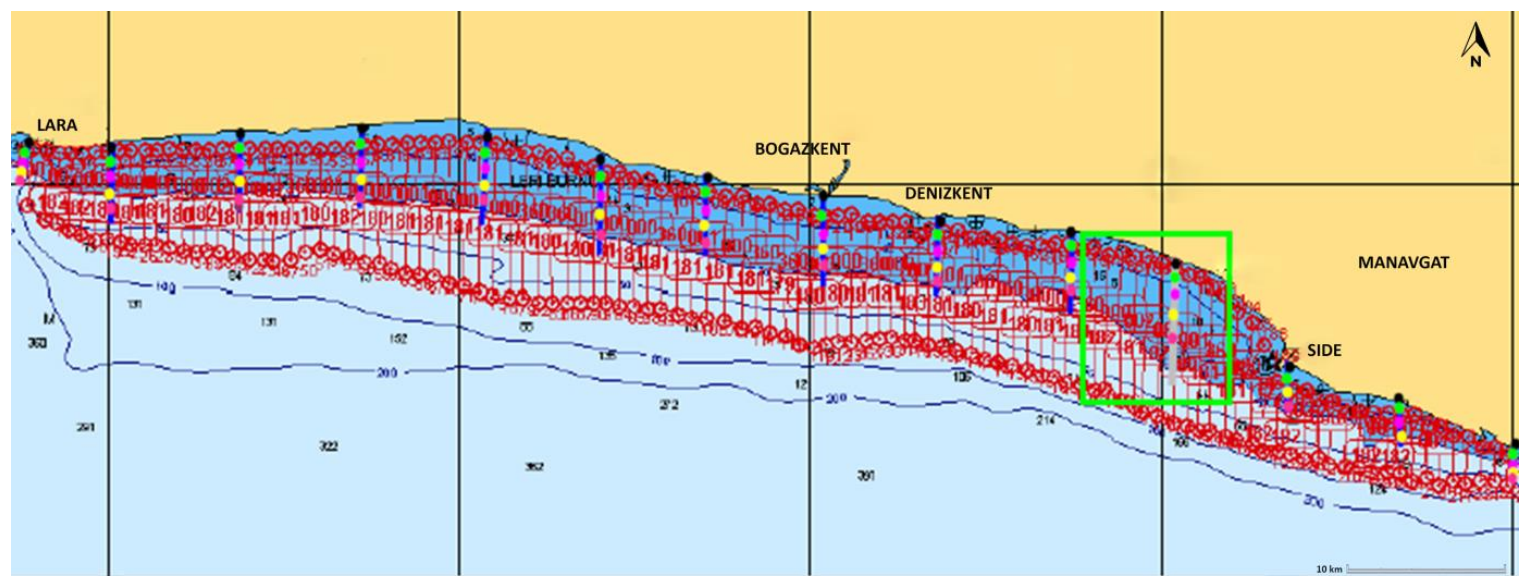

Figure 2. Survey description in the study area. Acoustic lines are displayed as red lines, and the green frame indicates the calibration locations.

In this study, the BioSonics EcoSAV ${ }^{\mathrm{TM}}$ and VBT Seabed Classifier (Visual Bottom Typer 1.10) software programs were used for post-processing of acoustic data to measure aquatic plant density. $P$. oceanica, the target species, has a plant threshold value of $-80-90 \mathrm{~dB}$; however, the program software requires a minimum plant threshold limit of $-65 \mathrm{~dB}$. This has caused some non-target species to be registered as target species. For this reason, a statistical analysis was performed using the PAST program to eliminate the non-target species. A twostep method was applied to analyze only those locations where $P$. oceanica existed. The first step involved configuration of EcoSAV parameters, and the second step concerned statistical extraction of $P$. oceanica from non-target species. In addition, new algorithms (AIPH: Acoustic Identification of Posidonia Height) were written using Matlab, in line with the specific requirements of each program related to output mapping.

To obtain spatial and temporal distributions of $P$. oceanica leaf height, species-specific calibrations of program parameters (Table 1) were performed to distinguish the species from other non-target species and to provide filtering.

$P$. oceanica was identified and screened using species-specific calibration of identification parameters contained in the program, which only analyzes regions with $P$. oceanica. However, owing to the effect of the plant threshold value mentioned above, non-target species were also included. In the raw EcoSAV data, leaf height data was typically concentrated around $0.5-0.6 \mathrm{~m}$; yet in some locations they reached $2 \mathrm{~m}$ (Figure 3 ).
Previous studies into the morphometric characteristics of $P$. oceanica have revealed maximum leaf heights distributed between 80 and $120 \mathrm{~cm}$ (Gacia and Duarte 2001; Sánchez-Carnero et al., 2012; Mutlu et al., 2014). For this reason, a plant height of $2 \mathrm{~m}$ is not possible. Measurement results from dives in the study area (Mutlu et al., 2014), and from the distribution map obtained during this study, correspond to a mean leaf height of $40-60 \mathrm{~cm}$. This value varies with season, but the maximum value, observed during the summer, was $0.90 \mathrm{~m}$. Therefore, a leaf height over $1 \mathrm{~m}$ is not possible, indicating the existence of non-target species/species with a different acoustic energy in our data (Figure 3a).

These non-target and/or unwanted factors were eliminated by performing cluster analysis. For this, we used a statistical program named PAST. The cluster analysis in the PAST program was applied on a single variable dependent on leaf height data obtained from EcoSAV. The purpose of this process was to provide clustering based on common features within the data itself. K-means clustering analysis is based on this principle. In addition, because the distance is calculated using the Euclidean distance formula, applying this formula with one, two, or three variables is not a problem. This process can be described by the simple mathematical expression:

Euclidean distance formula in one dimension: $\Sigma \mathrm{i}$ $=(y i-x i)$ where $\mathrm{i}$ is the number of variables or the number of columns. For $\mathrm{N}$ variables, $\mathrm{i}=\mathrm{N}$.

According to this formula, using K-means clustering analysis is preferable to a single variable because it is possible to measure the distance between two consecutive points even in one variable. 
However, there were some difficulties implementing the data recorded at each station, whereby the initial cluster number after cluster analysis of the data in the EcoSAV output file differed in each file. Thus, because no files start with the same cluster number, it was necessary to automate this control and write special software to enable selection from the numbered data. But this approach was successfully applied during this study.

Table 1. Configuration settings of EcoSAV program parameters (* is alterable with salinity, temperature and $\mathrm{pH}$ ).

\begin{tabular}{lc}
\hline Site specific & $\begin{array}{c}\text { Calibrated } \\
\text { parameter values }\end{array}$ \\
\hline Maximum number of OUT OF WATER pings per cycle & 2 \\
Maximum number of NOISY pings allowed in output per cycle & 3 \\
Maximum plant depth & 30 \\
System specific & \\
Calibration correction (dB) & 0 \\
Alpha (dB/m)* & 0.088 \\
Layer height (m) & 0.018 \\
Near field (m) & 1.13 \\
Advanced & \\
Threshold noise checking and plant detection & -65 \\
Noise checking distance depth increments & 6 \\
Plant height detection threshold & 23 \\
Bottom thickness threshold increments & 22 \\
Additional parameters & \\
Trailing edge of peak below sharpest rise at b1 & -140 \\
Ping bottom decision & 2 \\
Ping bottom adjustment & -30 \\
Cycle bottom depth decision & 6 \\
Plant feature echo intensity & 2 \\
Plant feature distance & 6 \\
Plant feature distance & 6 \\
Plant feature used in bottom thickness & 6 \\
Quiet threshold for bare bottom detection & 6 \\
Quiet threshold distance for bare bottom detection & 6 \\
Minimum number of good pings required to trigger a summary report & \\
\hline & \\
\hline
\end{tabular}

When the size distribution according to the data set obtained by sea-truth dives is considered, and the general morphometric properties of the $P$. oceanica species are examined, values other than the maximum leaf height (i.e. $2 \mathrm{~m}$ ) are filtered by automation. Once the distribution graph for the whole data set is obtained, it can be extracted manually by hand; however, this approach would be biased. As a result, unwanted data was eliminated owing to high and/or false acoustic reflection in the overall distribution. It should be noted that, without a plant threshold value to directly identify $P$. oceanica via EcoSAV, the data analyzed in Matlab could be assessed directly without the need for this secondary treatment. After the calibration process, a second filtering was performed on non-target species not already filtered out, thereby eliminating all unwanted target species (Figure 3b). 

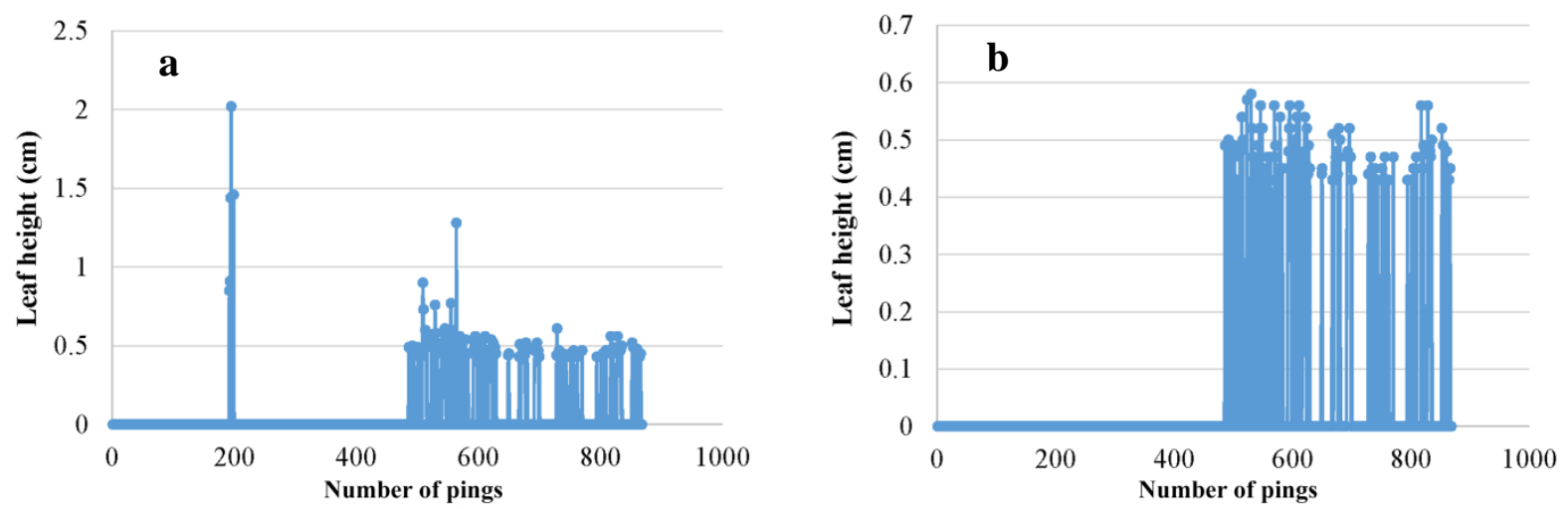

Figure 3. a) End result of analyses using the EcoSAV commercial program to determine leaf height. b) End result of analyses using the PAST program to isolate $P$. oceanica from non-target species.

Table 2. Configuration and setting of the VBT for detection and estimates of the echo strength of $P$. oceanica.

\begin{tabular}{ll}
\hline VBT parameters & Values \\
\hline Advanced Parameters & \\
\hline Data Processing Filter Threshold [dB] & -140 \\
TVG & $20 \mathrm{LogR}$ \\
Oscilloscope Options & Meters \\
Depth (X) Scale & Log \\
Amplitude (Y) Scale & \\
Bottom Sampling Windows & 6 \\
E1' (First Bottom First Part) (sample) & 97 \\
E1 (First Bottom Second Part) (sample) & 26 \\
E2 (Second Bottom Window) (sample) & 50 \\
S (Sediment Window) (sample) & \\
Bottom Tracking Window & -64 \\
Peak Threshold (dB) & 5 \\
Peak Width (sample) & -91 \\
Bottom Detection Threshold (dB) & 1 \\
Above Bottom Blanking Zone (sample) & 8 \\
Alarm Limit (sample) & 66 \\
Tracking Window (sample) & \\
Output Report Filters & 20 \\
Pings per Report & 60 \\
Energy filter (\%) & \\
\hline
\end{tabular}

The VBT was purposed to classify the bottom structures (BioSonics inc.). Therefore, detection of Posidonia oceanica was inspired from the detection of the bottom echo setting the parameter of VBT configuration to follow the meadow for the present study (Table 2). The advantageous of the VBT is to provide the data with echo level relative to the biomass of Posidonia leaves as compared with the EcoSav (Figure 4). The echo level of the P. oceanica was converted to relative acoustical energy or biomass per square meter area (sa) of the bottom with the trigonometric solution using the bottom depth and beam angle of the acoustical instrument. The absolute biomass was estimated with a relationship between the relative acoustical energy (sa) and leaf biomass estimated based on leaf area and leaf length during the SCUBA sampling (Figure 5).

In order to test whether the results of the acoustically determined distribution are correct, both the bottom type and bathymetry were determined to identify the boundaries of the distribution depth. For this purpose, VBT (Visual Bottom Type), a bottom type definition program, was used, and the process was performed using bottom echo signals. The B4 Fractal Dimension Method, which is included in the program, was chosen because of the fractal nature of the structure of the bottom. In addition, the bathymetry map of the study area was obtained from the acoustic data. 


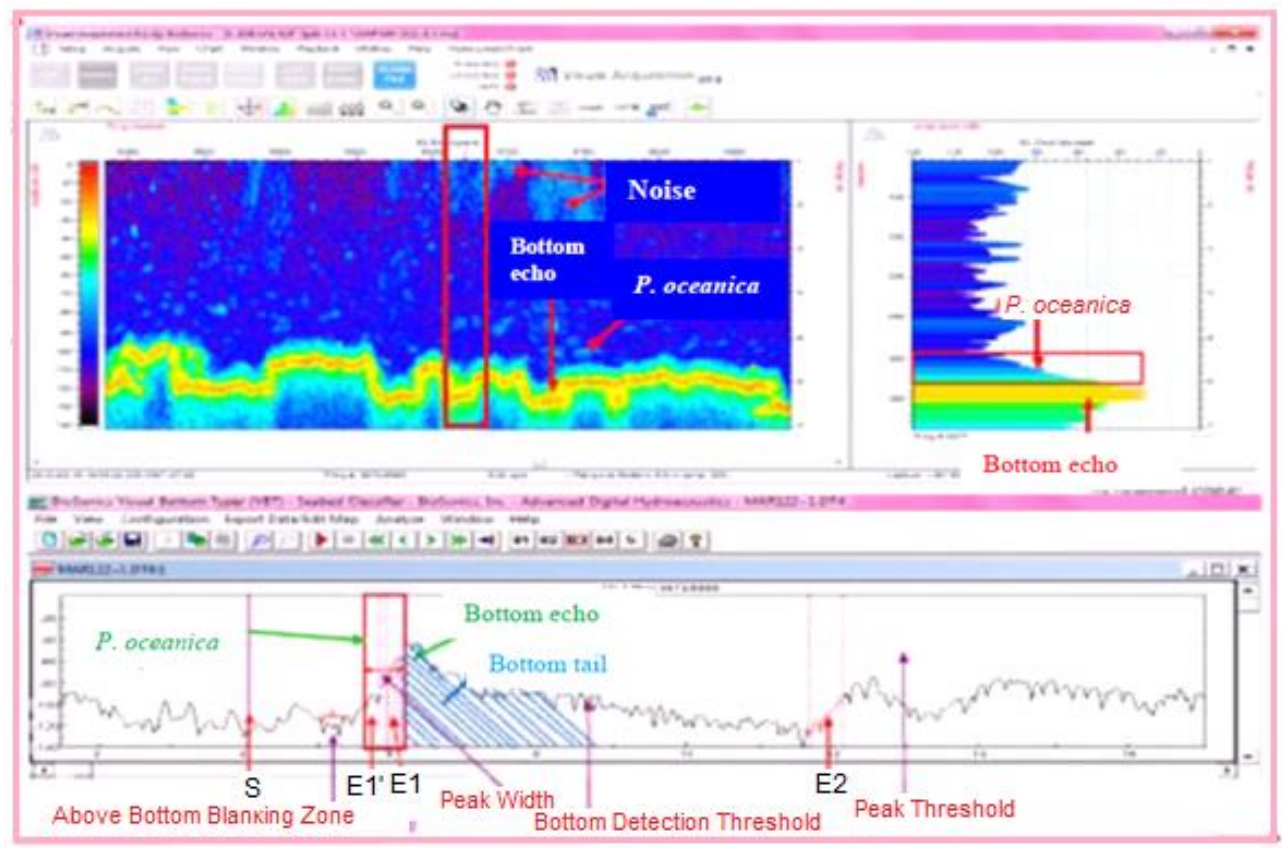

Figure 4. An echogram of the acoustical data and detection of the P. oceanica with the VBT commercial software.

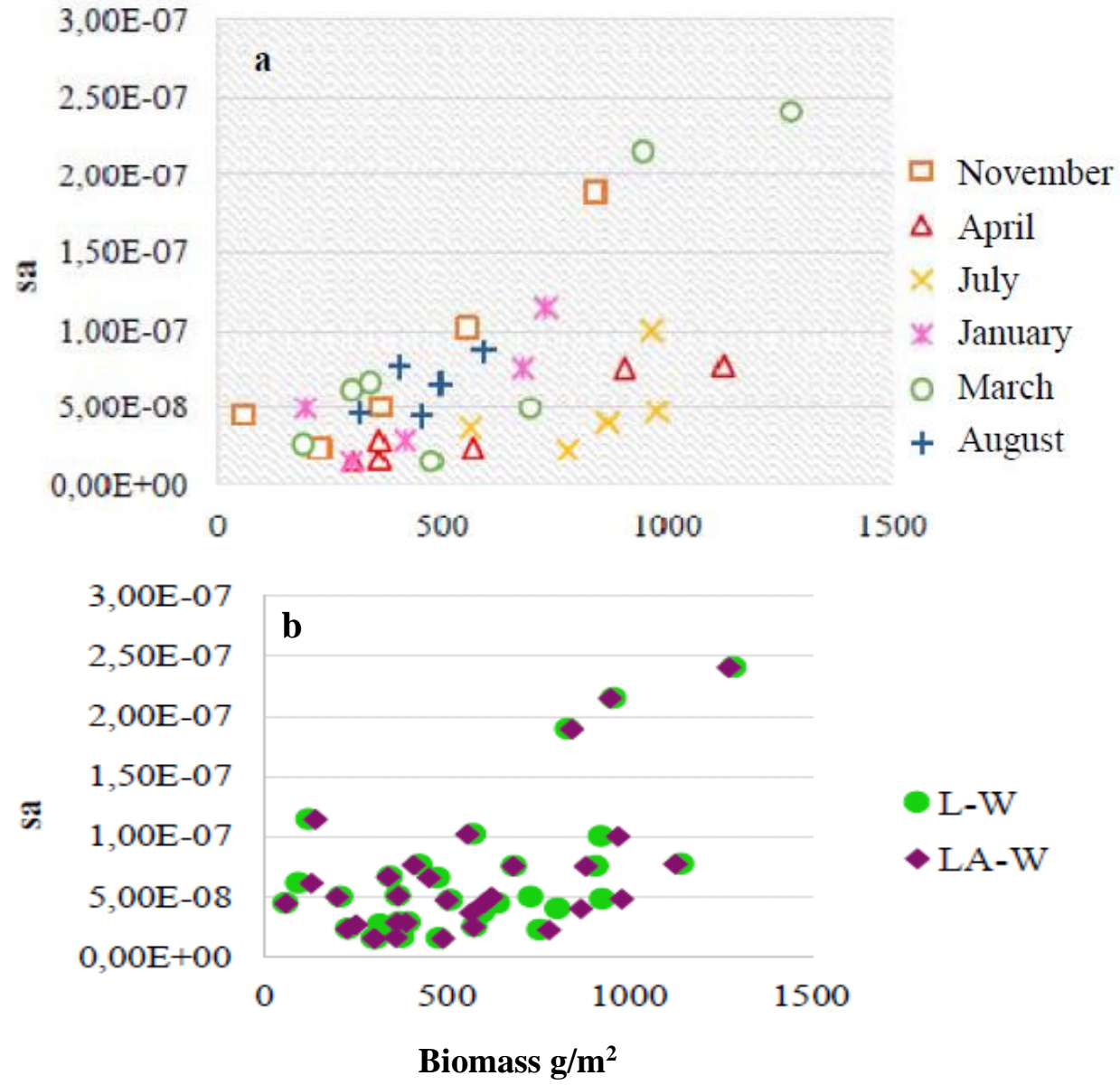

Figure 5. The correlation and regression of the leaf biomasses based on leaf area (a; LA-W) and leaf length (LW) of $P$. oceanica with the echo backscattering coefficients, sa, in square meter, estimated using the VBT. 


\section{Results}

The seasonal distribution of $P$. oceanica leaf heights after calibration is presented in Figure 6. According to this map, three different $P$. oceanica beds occur in the Antalya Gulf study area: off the coast of Bogazkent, Denizkent, and Side. Yellow lines show the acoustic lines in all seasons of the scanned area, revealing precise detection of the meadows (Figure 6).

It is clear that the areas within which $P$. oceanica is distributed (Figure 7a) and the depth (Figure 7b) are confined to those parts of the bottom that have a rocky slope.

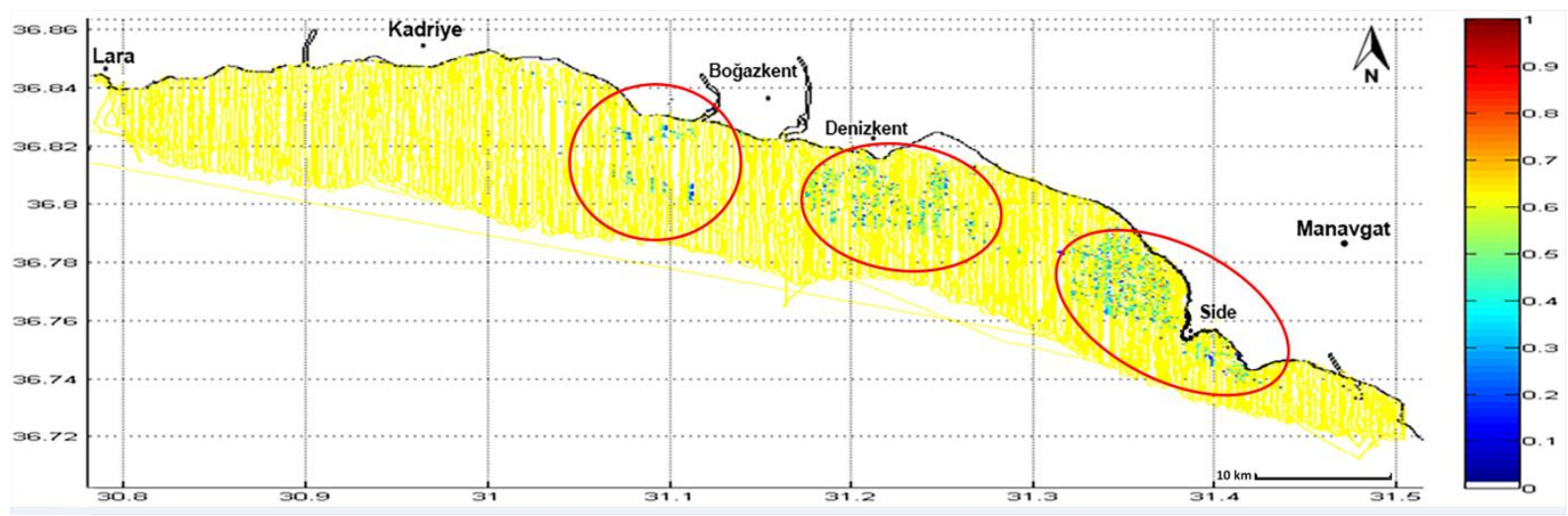

Figure 6. Leaf height $(\mathrm{m})$ distributions of $P$. oceanica obtained by the EcoSAV program combined with all seasonal data.
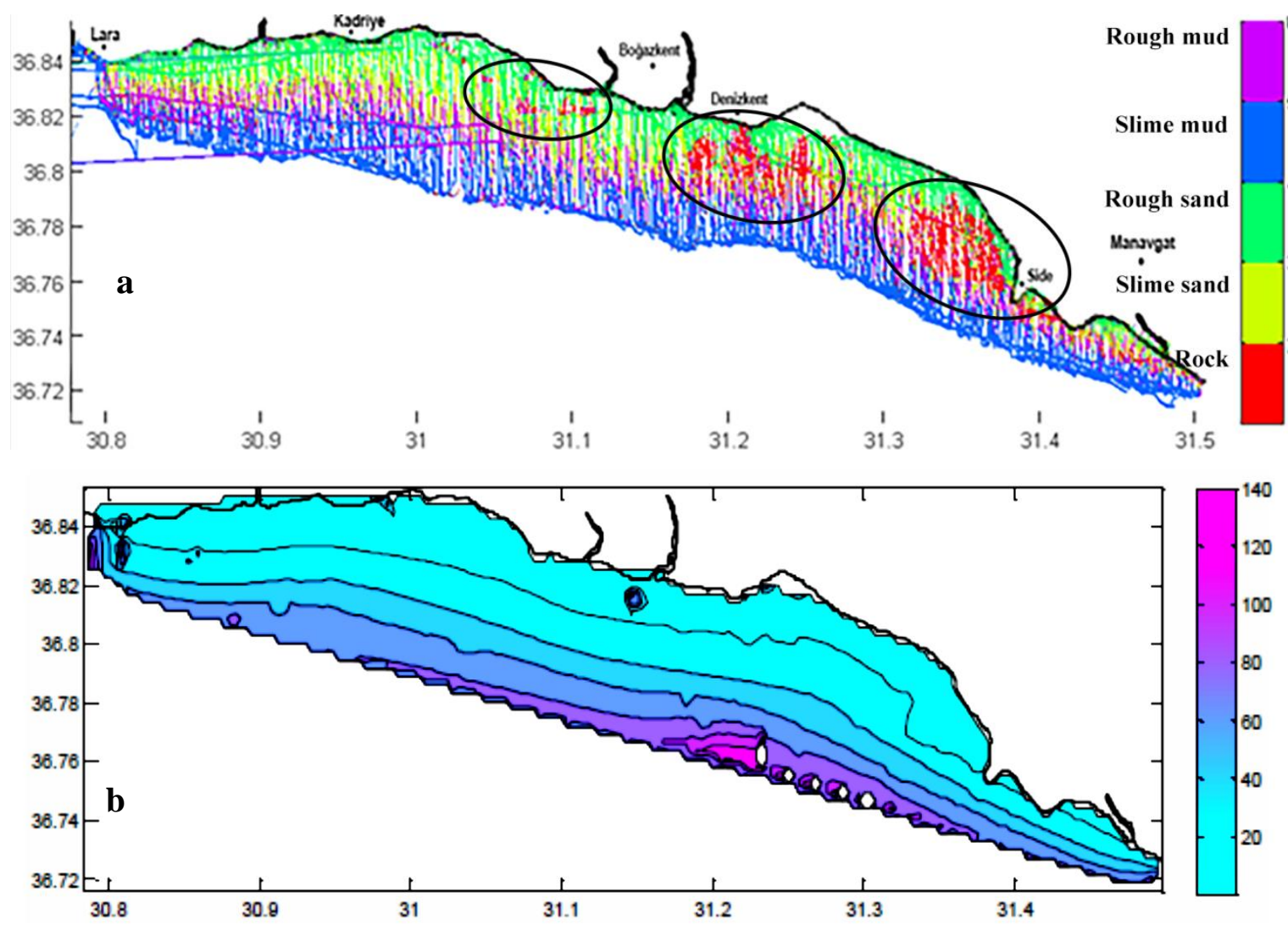

Figure 7. a) Distribution of the results for the bottom structure obtained by VBT on the acoustic lines.

b) Bathymetry (bottom depth on scale or color bar in $\mathrm{m}$ ) of the study area obtained from acoustic measurements. 
The highest leaf height was recorded in July (70$80 \mathrm{~cm}$, Figure $8 \mathrm{a}$ ), when $P$. oceanica meadows were observed in relatively small groups. A comparison of the bathymetry map obtained from acoustic measurements (Figure 8a) and the $P$. oceanica distribution map (Figure 8a) reveal clearly visible boundaries of depth distribution and seagrass beds that continue uninterrupted at depths of almost 25-30 $\mathrm{m}$ (Figure 8b). The depth of the bathymetry map was drawn to the maximum studied depth $(70 \mathrm{~m})$.

Compared to July, vegetation cover was decreased in November/December. Leaf height decreased significantly to $50-60 \mathrm{~cm}$ (Figure $8 \mathrm{~b}$ ).

In January, which is the coldest winter month in the region, leaf height was significantly lower than in the previous month, and the shortest plants were observed. It is noteworthy that $P$. oceanica showed a rather wide distribution in the Bogazkent region in July but, according to acoustic results for this month, $P$. oceanica was rarely found in this region (Figure $8 \mathrm{c})$.
In March, which marks the start of spring for vegetative growth and germination, new $P$. oceanica leaves began to emerge, and there was a recurrence in locations where it was not observed in January. Tall leaves were found towards Side, reaching a height of 70-80 cm (Figure 8d).

In April, noticeable growth in $P$. oceanica meadows was observed, with environmental conditions becoming more suitable (especially changes in temperature and salinity parameters). The longest leaves were distributed off the coast of Side, measuring 80-90 cm (Figure 8e).

Growth slowed down again at the end of the summer (August). According to SCUBA measurements, fresh leaves were less frequent, and long leaves, which had calcified and lost their freshness, were dominant in the overall distribution. The maximum leaf height was $70-80 \mathrm{~cm}$ in August. The ANOVA (one-way) test results of leaf height between seasons show that the average leaf length $(\mathrm{p}<0.05)$ is statistically different at the importance level according to the sampling period (Table 3).
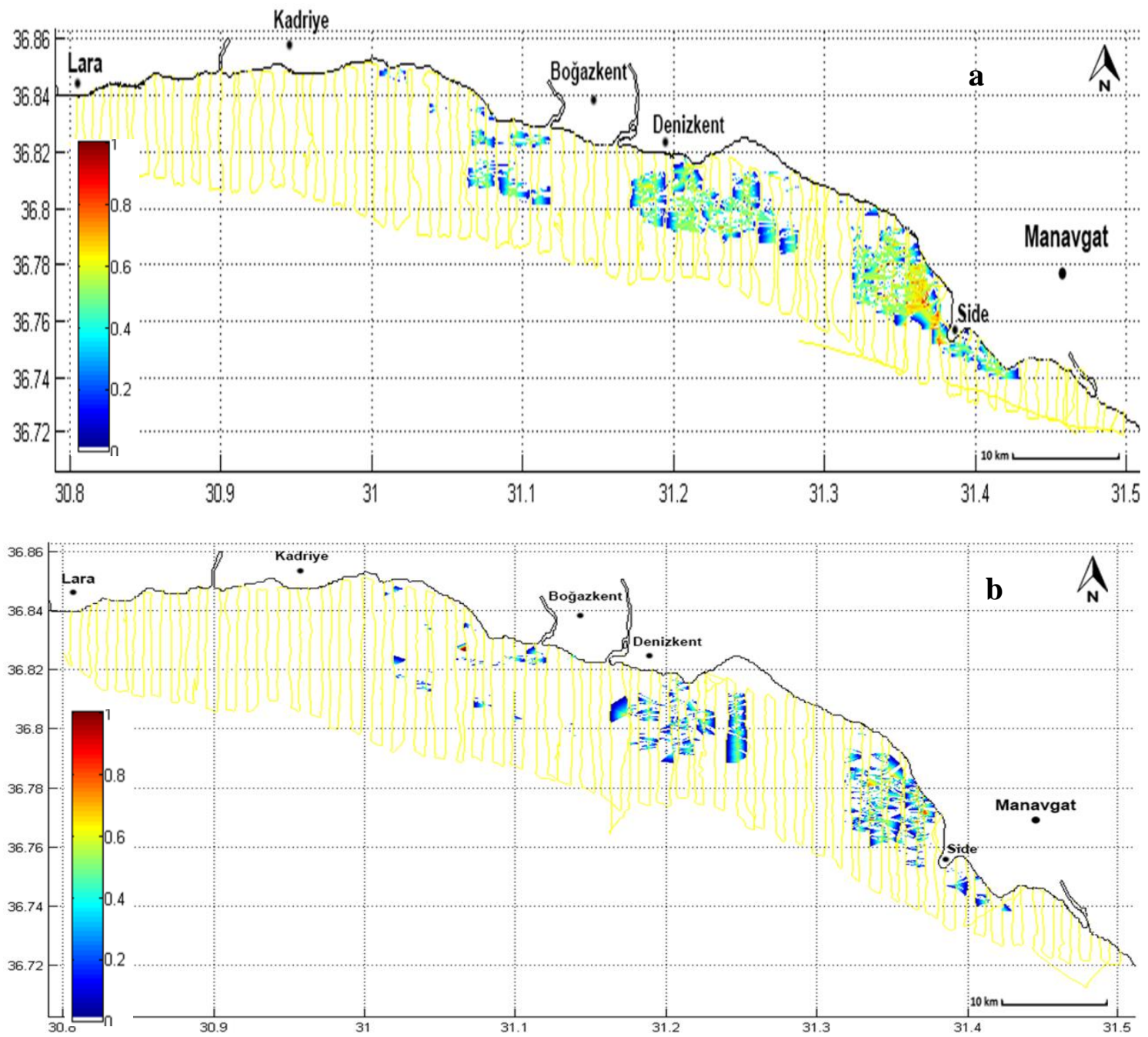

Figure 8. Continued 

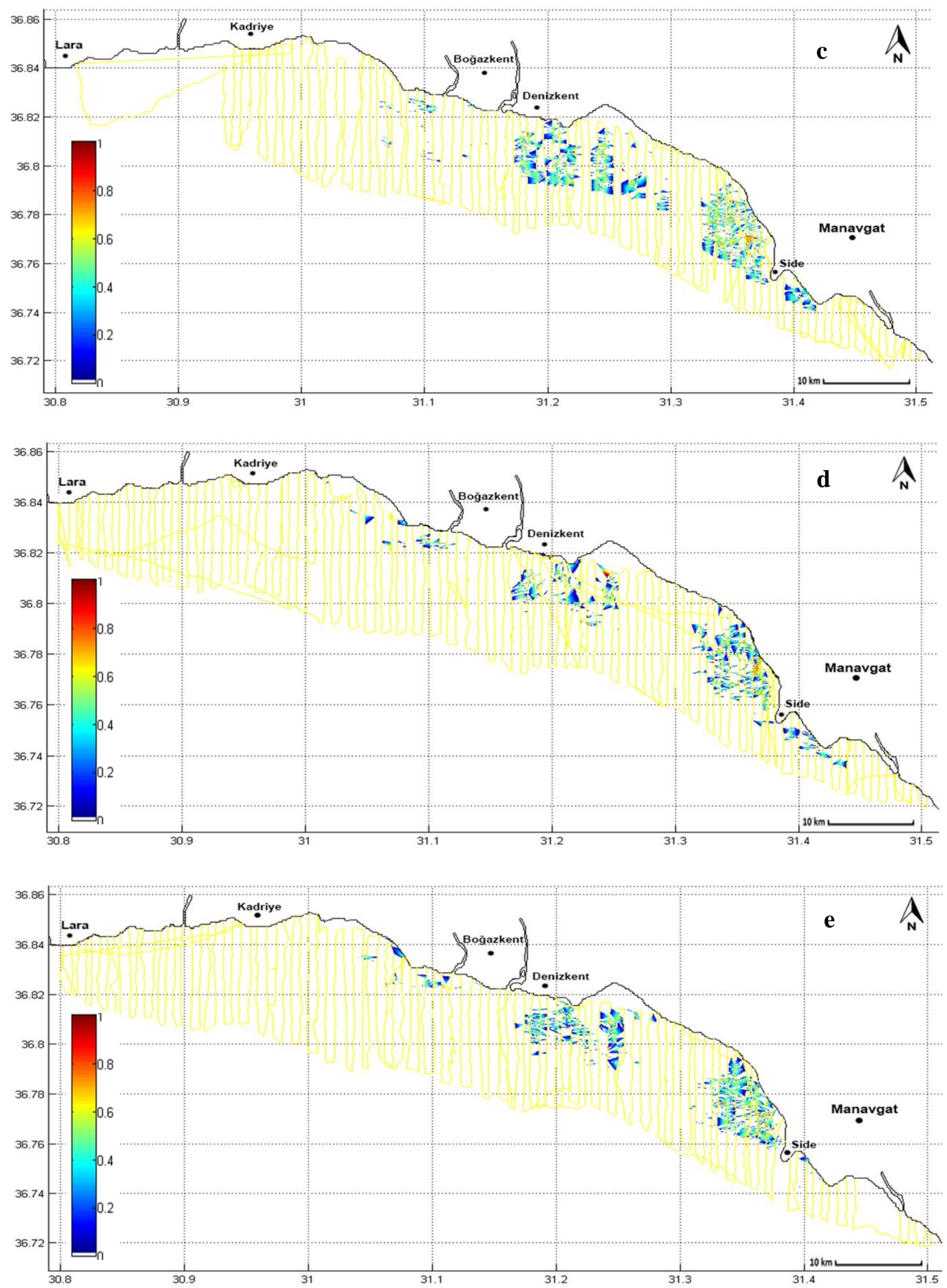

Figure 8. Seasonal distribution of $P$. oceanica leaf height ( $\mathrm{m}$ on scale or color bar) calculated by EcoSAV in July 2011 (a), November-December 2011 (b), January 2012 (c), March 2012 (d), and April 2012 (e). 
Table 3. ANOVA test results showing the statistical difference of the inter-seasonal leaf length of $P$. oceanica.

\begin{tabular}{lccccc}
\hline Factor & Sum of squares & d.f. & Mean square & F & P \\
\hline Season & $3.35107 \mathrm{e}+006$ & 6 & 558511.3 & 3288.68 & 0 \\
Error & $1.28829 \mathrm{e}+007$ & 75858 & 169.8 & & \\
Total & $1.62339 \mathrm{e}+007$ & 75864 & & & \\
\hline
\end{tabular}

According to Tukey's LSD post-hoc test results, the increase and decrease in average leaf length adequately expresses the temporal growth curve of the newly germinated individuals, and the process of leaf death is also well represented. The average leaf length was $\sim 15 \mathrm{~cm}$ in winter (Figure 9). The leaf biomass of $P$. oceanica varied between 100 and 1000 $\mathrm{g} / \mathrm{m}^{2}$ during the study period (Figure 10a). The minima were estimated in January-March and the maxima were in July-August-November. Seasonal biomass had high variations in all months with an exception of the biomass in August (Figure 10b). The biomass decreased by the bottom depth; the highest biomass at the shallower bottoms and the lowest biomass at the greater depths (Figure 10c).

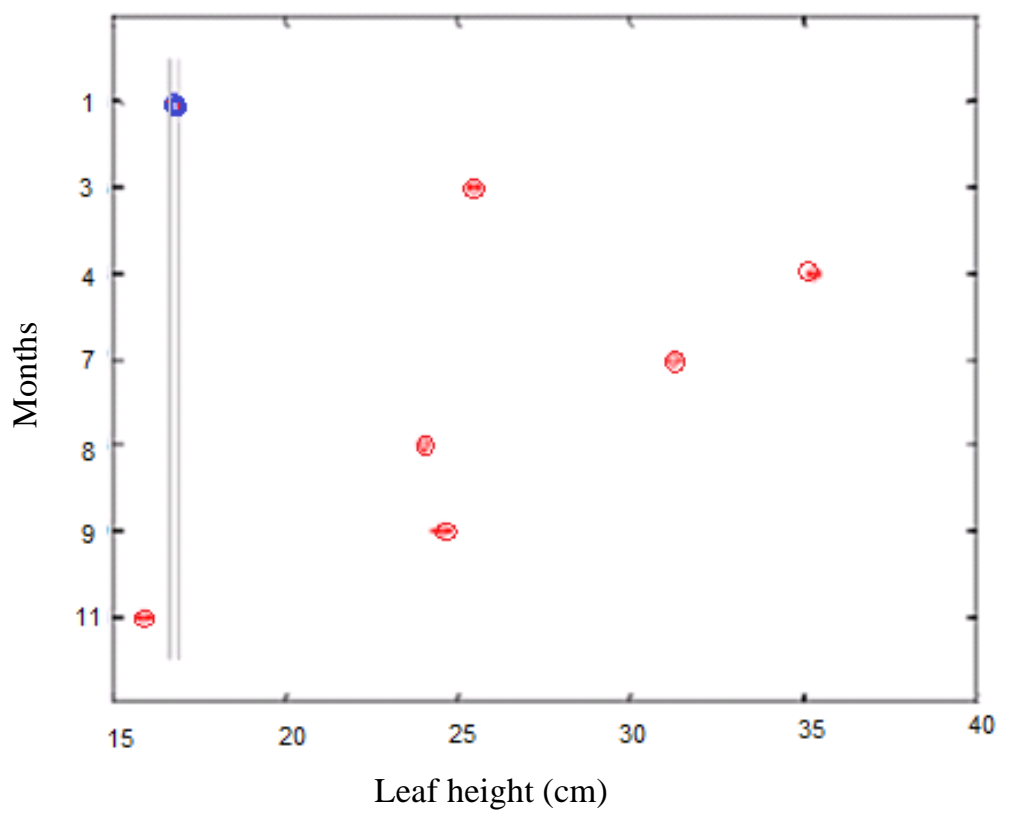

Figure 9. Average distribution of leaf length with season within 95\% confidence limits (Tukey's LSD post-hoc test).

\section{Discussion}

This study used data from Mutlu et al. (2014) to create an acoustic-based map of the distribution of $P$. oceanica's leaf height by species-specific calibration using the EcoSAV program. Some studies have previously been successful in using the EcoSAV program (McCarthy and Sabol, 2000), and problems arising from the program were overcome by special algorithms written by the researchers themselves (Stables, 2005; Depew et al., 2009; Mutlu et al., 2014). The problem we experienced owing to the program were overcome using PAST software; the minimum value of the plant threshold limit in the EcoSAV program algorithm was set much higher than the TS value of $P$. oceanica. Although we attempted a species-specific calibration, it was not possible to exclude different types of targets from the EcoSAV process. Thus, there is a need to either identify a special algorithm to eliminate the nontarget species, or use a simple-to-use statistical method. We chose the latter in this study.

Elimination of other non-target species both within the distribution range of $P$. oceanica and at depths of $50 \mathrm{~m}$ and above was successfully performed after the PAST process. Compared with the echogram, the TS values of the sections filtered by the PAST software were not found to belong to $P$. oceanica. 

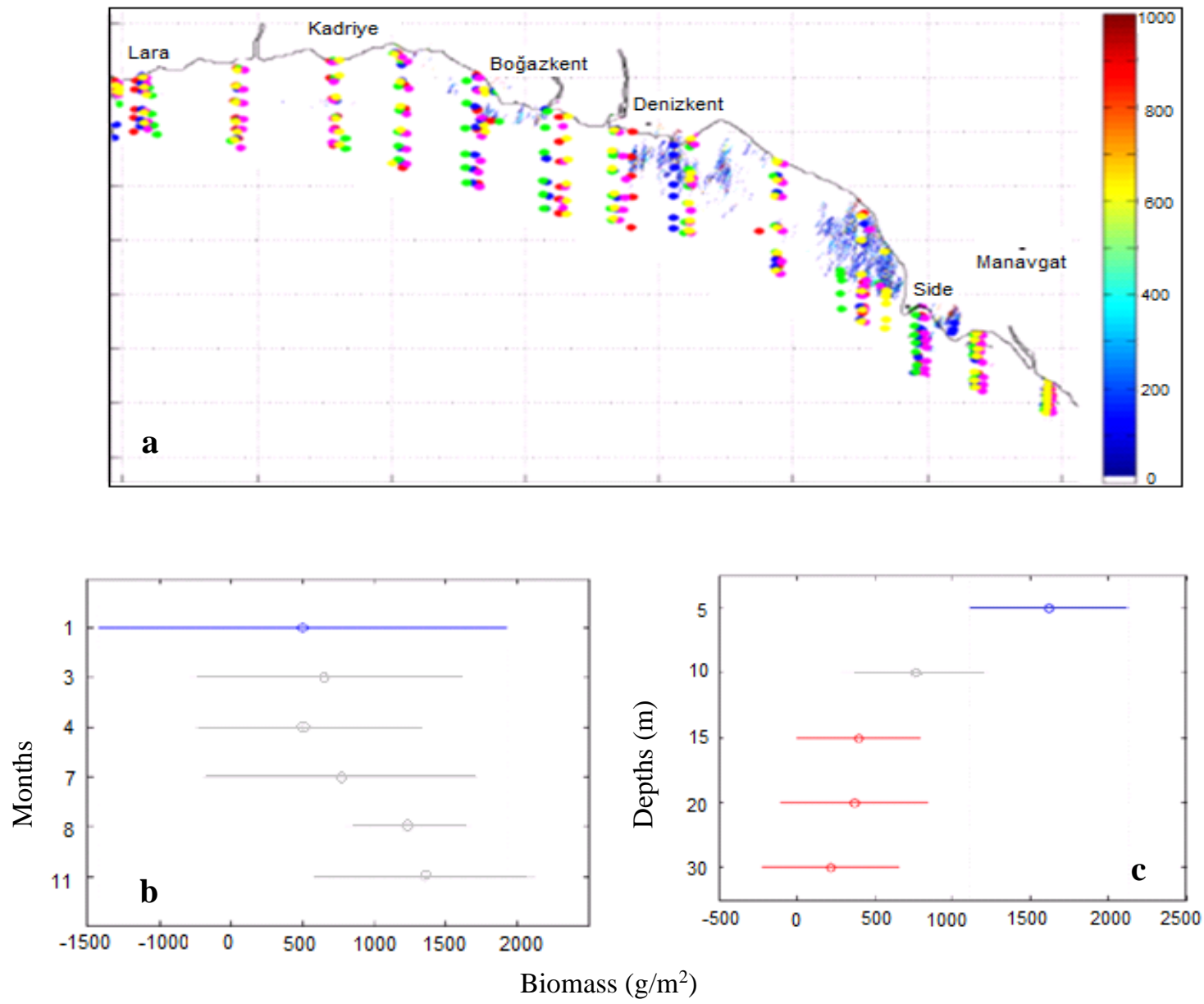

Figure 10. The absolute leaf biomass $\left(\mathrm{g} / \mathrm{m}^{2}\right.$ on color bar) of $P$. oceanica during the all surveys in the Gulf of Antalya (a) and seasonal SCUBA diving stations (dots). Monthly (b) and depthwise in m (c) distribution of the leaf biomass (Average and 95\% confidence limits, Tukey's LSD post-hoc test).

The PAST program used for this purpose allows us to perform the desired classification in a single data set, and successfully applies it to all other data sets. All these calibrations are shown when the distribution map is plotted with an algorithm written in Matlab. Interestingly, another study also encountered issues with the EcoSAV algorithm (Depew et al. 2009), where the pre-release version of EcoSAV (e.g. v2.0) was required because the first version of the EcoSAV v1.0 program did not allow threshold values to be set lower than $-80 \mathrm{~dB}$ for plant cover detection (BioSonics2001). This situation during our study allowed $P$. oceanica (TS value at $80-90 \mathrm{~dB})$ to be partially calibrated. In addition, Depew et al. (2009) reported that the EcoSAV program may give misleading results in rocky areas, so that differences may arise between sea-truth data and acoustic data obtained via EcoSAV. It is thus particularly difficult to acoustically determine and identify $P$. oceanica, which prefers rocky habitats owing abrupt changes in bottom depth (Depew et al., 2009). We attempted to eliminate this problem to the extent possible using both the PAST software and the fine setting of EcoSAV parameters.
When dealing with very large amounts of data, it is important to choose an easily applicable method. Thus, we chose the K-means clustering analysis in the PAST program. However, the correct choice of the number of clusters to perform the right process depends on trial and error.

After this process was completed, the results showed that a decline in the distribution of $P$. oceanica leaf height occurred from summer to winter, and plant leaf height distribution began to increase once more in March. The tallest leaf was found in July $(90 \mathrm{~cm})$, and the shortest leaf was found in November/December (below $15 \mathrm{~cm}$ ). The reason for this is that leaf length in winter decreases to almost below $10 \mathrm{~cm}$, and the acoustic dead zone is calculated as $7.5 \mathrm{~cm}$ for winter. If a region of $P$. oceanica enters the dead zone, it will be identified as empty because $P$. oceanica is not correctly identified. This explains the seasonal difference in $P$. oceanica distribution, especially in winter. Mutlu et al. (2014) and Mutlu \& Balaban (2018) obtained a similar result using their own algorithm. However, when they disregarded their algorithm and processed the acoustic data using the EcoSAV program according to the default 
parameters, they obtained results different from those of this study.

The resulting distribution maps (Mutlu et al., 2014) do not agree with the results obtained in this study. The distribution of $P$. oceanica meadows was parallel to the coast in open waters (defined as depths greater than $50 \mathrm{~m}$ ) and leaf heights were greater than $1 \mathrm{~m}$. However, these are false values because the bathymetric maps extend to $30 \mathrm{~m}$ depth within the specified boundaries. Mutlu and Balaban (2018) reported that both ground-truths and grab sampling results were limited to $30 \mathrm{~m}$ of the species distribution, and that recordings were not obtained at greater depths. Therefore, within the study area, distributions of $P$. oceanica on only rocky or hard gravel sediments do not indicate the presence of species at depths greater than $30 \mathrm{~m}$, because the sediment properties have changed and they are not conducive to their growth (Figure 5a). The maps also suggest that $P$. oceanica meadows were found in the Lara region, with leaf heights of over $1 \mathrm{~m}$. However, according to our acoustic measurements and data obtained from dive expeditions, $P$. oceanica species were not found in the Lara region.

Previous studies determined a maximum plant height of $P$. oceanica of $1 \mathrm{~m}$, depending on the season (Balestri et al. 2004; Ciraolo et al., 2006). Gacia and Duarte (2001) observed steady plant growth over a year, and recorded a maximum height of $80 \mathrm{~cm}$ in July. These findings are consistent with the results of the acoustical seasonal distribution of $P$. oceanica obtained in this study. Previous studies on the distribution of $P$. oceanica along the Turkish coast (apart from Mutlu \& Balaban, 2018) revealed that leaf height is higher in summer and lower in winter (Cirik et al., 2006; Alaçam et al., 2007; Akçali et al., 2008), but the height values obtained from these studies were well below those determined in this study. The reason for this is that in summer mean-water temperature in the Marmara Sea $\left(26^{\circ} \mathrm{C}\right)$ is cooler than that in the Mediterranean, and temperature changes the photosynthesis and growth characteristics of seagrasses. In another survey conducted on the Turkish Mediterranean Coast (Northeast Levantine Sea), leaf heights were highest in summer and lower during the winter season (Celebi et al., 2007), and were consistent with our results. We conclude that the spatial and temporal variations of $P$. oceanica distribution determined in this study are consistent with those of previous studies. In addition, these comparable results clearly demonstrate the effectiveness of both our new methodology and EcoSAV program calibration to identify $P$. oceanica.

The leaf biomass was homogenously distributed in August whereas the spatial distributions of the biomasses were heterogeneous in other sampling months in the study area. This homogeneity could be due to leaf breakage season in late summer. The old leaves were demised during August-September (Balestri \& Cinelli 2003). However, the leaf biomass estimations were found within the ranges of another study (Mutlu \& Balaban, 2018). There were some seasonal and depth wise differences in the biomass estimations between the present study and a study published by Mutlu \& Balaban (2018).

\section{Conclusion}

This study used a 206-kHz split-beam echo sounder combined with the EcoSAV and VBT software program to determine how the leaf height and biomass distribution of $P$. oceanica varied spatially and temporally. Vital information regarding the dynamics and population size of these meadows, some of which has not previously been studied, was obtained. Our results contribute previously unknown knowledge of this species, and provide valuable information related to the health and distribution of $P$. oceanica meadows along the coast of Turkey in the eastern Mediterranean, which has previously received limited research attention.

We also showed that software commonly used for vegetation acoustic studies, which uses speciesspecific acoustic characteristics, can be more effective if the program is calibrated first. In addition to this, we highlight the usefulness of vegetation acoustic studies as an effective way to map and monitor important seasonal habitat parameters, such as the distribution of aquatic vegetation. This method can also be applied to other similar areas. Monitoring of protected $P$. oceanica seagrass is important for studying the responses of the $P$. oceanica ecosystem to changing environmental conditions. The biomass estimations would be improved by the combination of these two methods applied in the present study for the future works.

\section{Acknowledgements}

This work was funded by the TUBITAK 110 Y232 project. We gratefully acknowledge the captain and crew of R/V Akdeniz $\mathrm{Su}$ for their efforts during data acquisition. This study is a part of Cansu Balaban (Olguner)'s PhD thesis. We would like to thank M. Tunca Olguner for his important contributions, Editage (www.editage.com) for English language editing and anonymous reviewers of their helpful suggestions.

\section{References}

Akçali, B., Bizsel, K.C., Kaboglu, G., Güçlüsoy, H., \& Alaçam, Ö. (2008). Foça Özel Çevre Koruma Bölgesinde Deniz Çayırları (Posidonia oceanica) İzleme Ön Çalışması., SBT-2008 12. Sualtı Bilim ve Teknoloji Toplantısı, BORNOVA, Kasım, SBT 08 pp. 69-75. 
Alaçam, Ö., Altay, S., Eren, S., Ergin, M., Gençoğlu, G., Kirbulut, D., \& Koban, E. (2007). Küçükkuyu-Assos-Bababurun Bölgesinde Posidonia oceanica (L) Delile Yayılımının İncelenmesi, XI. Sualtı Bilim ve Teknoloji Toplantısı, Koç Üniversitesi, İstanbul., pp. 110114.

Augier, H., 1985. L'herbier à Posidonia oceanica, son importance pour le littoral méditerranéen, sa valeur comme indicateur biologique de l'état de santé de la mer, son utilisation dans la surveillance du milieu, les bilans écologiques et les études d'impact. Vie Marine 7, 85-113.

Balestri, E., \& Cinelli, F. (2003). Sexual reproductive success in Posidonia oceanica. Aquatic Botany, 75, 21-32. https://doi.org/10.1016/S03043770(02)00151-1

Balestri, E. (2004). Flowering of the seagrass Posidonia oceanica in a north-western Mediterranean coastal area: temporal and spatial variations. Marine Biology, 145:61-68. DOI: $10.1007 / \mathrm{s} 00227-004-1301-2$

Bhattacharya, B., Sarkar, S., \& Das, R. (2003). Seasonal variations and inherent variability of selenium in marine biota of a tropical wetland ecosystem: implications for bioindicator species. Ecological Indicators, 2, 367-375. https://doi.org/10.1016/S1470-160X(03)00006-2

Bonacorsi, M., Pergent-Martini, C., Breand, N., \& Pergent, G. (2013). Is Posidonia oceanica regression a general feature in the Mediterranean Sea? Mediterranean Marine Science, 14, 193203. DOI: $10.12681 / \mathrm{mms} .334$

Boudouresque, C.-F., Bernard, G., Pergent, G., Shili, A., \& Verlaque, M. (2009). Regression of Mediterranean seagrasses caused by natural processes and anthropogenic disturbances and stress: a critical review. Botanica Marina, 52, 395-418. DOI: 10.1515/BOT.2009.057

Buchet, V., (2015). Impact assessment of invasive flora species in Posidonia oceanica meadows on fish assemblage: an influence on local fisheries? the case study of Lipsi Island, Greece. MsC Thesis. 99 p.

Celebi, B., Gucu, A., Ok, M., Serdar, S., \& Akoglu, E. (2007). Survival of the Posidonia oceanica cuttings transplanted into the north-eastern Levant Sea. Rapp Comm Int Mer Medit 38, 446.

Ciraolo, G., Ferreri, G.B., \& Loggia, G.L. (2006). Flow resistance of Posidonia oceanica in shallow water. Journal of Hydraulic Research, 44, 189202.

https://doi.org/10.1080/00221686.2006.9521675
Cirik, Ş., Akçalı, B., \& Özalp, H.B. (2006). Çanakkale Boğazı ve Marmara Denizi'nde işaretleme yöntemi ile Posidonia oceanica'nın sınırlarının belirlenmesi, E. U. Su Ürünleri Dergisi, 23, 45-48.

Depew, D.C., Stevens, A.W., Smith, R.E., \& Hecky, R.E. (2009). Detection and characterization of benthic filamentous algal stands (Cladophora sp.) on rocky substrata using a high-frequency echosounder. Limnology and Oceanography: Methods,7,693-705.

https://doi.org/10.4319/lom.2009.7.693

Di Maida G., Tomasello A., Luzzu F., Scannavino A., Pirrotta M., Orestano C., \& Calvo, S. (2011). Discriminating between Posidonia oceanica meadows and sand substratum using multibeam sonar. ICES Journal of Marine Science, 68: 1219. DOI:10.1093/icesjms/fsq130

Duman, M., Eronat, A.H., İlhan T., Talas E., \& Küçüksezgin F. (2019). Mapping Posidonia oceanica (Linnaeus) Meadows in the Eastern Aegean Sea Coastal Areas of Turkey: Evaluation of Habitat Maps Produced Using the Acoustic Ground Discrimination Systems. International Journal of Environment and Geoinformatics, 6(1):67-75. DOI:10.30897/ijegeo.544695

Elliott, J., Fletcher, J., Elliott, J., Cubby, P., \& Baroudy, E. (1996). Changes in the population density of pelagic salmonids in relation to changes in lake enrichment in Windermere (northwest England). Ecology of Freshwater Fish, 5,153-162.

DOI: 10.1111/j.1600-0633.1996.tb00128.x

Farrell, J.L., Harrison, J.P., Eichler, L.W., Sutherland, J.W., Nierzwicki-Bauer, S.A., \& Boylen, C.W. (2013). Identification of Eurasian watermilfoil using hydroacoustics. Journal of Aquatic Plant Management, 51, 15-21.

Foden, J., \& Brazier, D. (2007). Angiosperms (seagrass) within the EU water framework directive: a UK perspective. Marine Pollution Bulletin,55,181-195. https://doi.org/10.1016/j.marpolbul.2006.08.021

Gacia, E., \& Duarte, C.M. (2001). Sediment retention by a Mediterranean Posidonia oceanica meadow: the balance between deposition and resuspension. Estuarine, Coastal and Shelf Science, 52, 505514. DOI: $10.1006 /$ ecss.2000.0753

George, D., \& Winfield, I. (2000). Factors influencing the spatial distribution of zooplankton and fish in Loch Ness, UK. Freshwater Biology, 43,557-570.

DOI: $10.1046 / \mathrm{j} .1365-2427.2000 .00539 . \mathrm{x}$ 
Giakoumi, S., Sini, M., Gerovasileiou, V., Mazor, T., Beher, J., Possingham, H.P., Abdulla, A., Çinar, M.E., Dendrinos, P., Gucu, A.C., Karamanlidis, A.A., Rodic, P., Panayotidis, P., Taskin, E., Jaklin, A., Voultsiadou, E., Webster, C., Zenetos, A., \& Katsanevakis, S. (2013). Ecoregion-Based Conservation Planning in the Mediterranean: Dealing with Large-Scale Heterogeneity. PLOS $O N E, 8, \mathrm{e} 76449$.

https://doi.org/10.1371/journal.pone.0076449

Holon, F., Boissery, P., Guilbert, A., Freschet, E., \& Deter, J. (2015). The impact of 85 years of coastal development on shallow seagrass beds (Posidonia oceanica L. (Delile)) in South Eastern France: A slow but steady loss without recovery. Estuarine, Coastal and Shelf Science, 165, 204-212. https://doi.org/10.1016/j.ecss.2015.05.017

IUCN, 2017. The IUCN Red List of Threatened Species. Version 2017-2. www. iucnredlist.org. http://www.iucnredlist.org/details/153534/0.

Downloaded on 21 November 2017.

Komatsu, T., Mikami, A., Sultana, S., Ishida, K., Hiraishi, T., \& Tatsukawa, K.-I. (2003). Hydroacoustic methods as a practical tool for cartography of seagrass beds. Otsuchi Marine Science, 28:72-79.

Marbà, N., Díaz-Almela, E., \& Duarte, C.M. (2014). Mediterranean seagrass (Posidonia oceanica) loss between 1842 and 2009. Biological Conservation, 176,183-190.

DOI:10.1016/J.BIOCON.2014.05.024

Marín-Guirao, L., Sandoval-Gil, J.M., BernardeauEsteller, J., Ruíz, J.M., \& Sánchez-Lizaso, J.L. (2013). Responses of the Mediterranean seagrass Posidonia oceanica to hypersaline stress duration and recovery. Marine Environmental Research, 84, 60-75. DOI: 10.1016/j.marenvres.2012.12.001

McCarthy, E.M., \& Sabol, B. (2000). Acoustic characterization of submerged aquatic vegetation: military and environmental monitoring applications, OCEANS 2000 MTS/IEEE Conference and Exhibition. IEEE, pp. 1957-1961.

Montefalcone, M. (2009). Ecosystem health assessment using the Mediterranean seagrass Posidonia oceanica: a review. Ecological Indicators, 9,595-604. https://doi.org/10.1016/j.ecolind.2008.09.013

Montefalcone, M., Rovere, A., Parravicini, V., Albertelli, G., Morri, C., \& Bianchi, C.N. (2013). Evaluating change in seagrass meadows: A timeframed comparison of Side Scan Sonar maps. Aquatic Botany, 104, 204-212. https://doi.org/10.1016/j.aquabot.2011.05.009
Mutlu, E., Gökoğlu, M., Özvarol, Y., Balaban, C., \& Olguner, T. (2014). Yaygın deniz çayırlarının akustiksel yoğunluk kalibrasyonu ve dağılımlarının takip edilmesi. Final Raporu. TÜBİTAK 110 Y232.

Mutlu, E. \& Balaban, C. (2018). New algorithms for the acoustic biomass estimation of Posidonia oceanica: a study in the Antalya gulf (Turkey), Fresenius Environmental Bulletin, 27(4), 25552561.

Pasqualini, V., Pergent-Martini, C., Clabaut, P., \& Pergent, G. (1998). Mapping of Posidonia oceanica using aerial photographs and side-scan sonar: application of the island of Corsica (France). Estuarine, Coastal and Shelf Science, 47(3),359-367. https://doi.org/10.1006/ecss.1998.0361

Pergent-Martini, C., Leoni, V., Pasqualini, V., Ardizzone, G., Balestri, E., Bedini, R., Belluscio, A., Belsher, T., Borg, J., \& Boudouresque, C. (2005a). Descriptors of Posidonia oceanica meadows: Use and application. Ecological Indicators, 5,213-230.

DOI: $10.1016 /$ j.ecolind.2005.02.004

Pergent-Martini, C., Leoni, V., Pasqualini, V., Ardizzone, G.D., Balestri, E., Bedini, R., Belluscio, A., Belsher, T., Borg, J., Boudouresque, C.F., Boumaza, S., Bouquegneau, J.M., Buia, M.C., Calvo, S., Cebrian, J., Charbonnel, E., Cinelli, F., Cossu, A., Maida, G.D., Dural, B., Francour, P., Gobert, S., Lepoint, G., Meinesz, A., Molenaar, H., Mansour, H.M., Panayotidis, P., Peirano, A., Pergent, G., Piazzi, L., Pirrotta, M., Relini, G., Romero, J., SanchezLizaso, J.L., Semroud, R., Shembri, P., Shili, A., Tomasello, A., \& Velimirov, B. (2005b). Descriptors of Posidonia oceanica meadows: Use and application. Ecological Indicators, 5, 213230. DOI: $10.1016 /$ j.ecolind.2005.02.004

Pergent-Martini, C., \& Pergent, G. (2000). Marine phanerogams as a tool in the evaluation of marine trace-metal contamination: an example from the Mediterranean. International Journal of Environment and Pollution, 13, 126-147. DOI: 10.1504/IJEP.2000.002313

Prado, P., Alcoverro, T., \& Romero, J. (2010). Influence of nutrients in the feeding ecology of seagrass (Posidonia oceanica L.) consumers: a stable isotopes approach. Marine Biology, 157: 715-724. DOI: $10.1007 / \mathrm{s} 00227-009-1355-2$

Sabol, B.M., Burczynski, J., \& Hoffman, J. (2002). Advanced digital processing of echo sounder signals for characterization of very dense submersed aquatic vegetation. DTIC Document. 
Sabol, B.M., Kannenberg, J., \& Skogerboe, J. (2009). Integrating acoustic mapping into operational aquatic plant management: a case study in Wisconsin. Journal of Aquatic Plant Management, 47, 44-52.

Sánchez-Carnero, N., Rodríguez-Pérez, D., Couñago, E., Aceña, S., \& Freire J. (2012). Using vertical Sidescan Sonar as a tool for seagrass cartography. Estuarine, Coastal and Shelf Science, 115: 334344. DOI: 10.1016/j.ecss.2012.09.015

Schmidt, M., Gassner, H., \& Meyer, E. (2005). Distribution and biomass of an underfished vendace, Coregonus albula, population in a mesotrophic German reservoir. Fisheries Management and Ecology, 12, 169-175. DOI: $10.1111 / \mathrm{j} .1365-2400.2005 .00439 . \mathrm{x}$

Schneider, P., Burczynski, J., Monteoliva, A., \& Valle, A. (2001). Results from submerged aquatic plant assessment using digital echosounder technique. International Council for the Exploration of the Sea, Joint Session of FTFB and FAST Working Groups, 23-27.

Spalding, M., Taylor, M., Ravilious, C., Short, F., \& Green, E. (2003). The distribution and status of seagrasses. World atlas of seagrasses. University of California Press, Berkeley, California, 5-26.

Stables, B. (2005). Hydroacoustic Survey of Aquatic Plants In Cultus Lake, Bc Conducted August 1618, 2004: Mapping of Plant Density \& Depth of Canopy Top. Shuksan Fisheries Consulting, Final Report., Everson, WA, USA., p. 19.

Telesca, L., Belluscio, A., Criscoli, A., Ardizzone, G., Apostolaki, E., Fraschetti, S., Gristina, M., Knittweis, L., Martin, C., \& Pergent, G. (2014). Seagrass meadows (Posidonia oceanica) distribution and trajectories of change. Scientific Reports,5,12505-12505. DOI: 10.1038/srep12505

Valley, R.D., Drake, M.T., \& Anderson, C.S. (2005). Evaluation of alternative interpolation techniques for the mapping of remotely-sensed submersed vegetation abundance. Aquatic Botany, 81: 13-25. https://doi.org/10.1016/j.aquabot.2004.09.002

Wanzenböck, J., Mehner, T., Schulz, M., Gassner, H., \& Winfield, I.J. (2003). Quality assurance of hydroacoustic surveys: the repeatability of fishabundance and biomass estimates in lakes within and between hydroacoustic systems. ICES Journal of Marine Science, 60, 486-492. https://doi.org/10.1016/S1054-3139(03)00030-4
Winfield, I., Onoufriou, C., O'Connell, M., Godlewska, M., Ward, R., Brown, A., \& Yallop, M. (2007). Assessment in two shallow lakes of a hydroacoustic system for surveying aquatic macrophytes. Hydrobiologia, 584, 111-119. DOI: $10.1007 / \mathrm{s} 10750-007-0612-\mathrm{y}$

Yücel-Gier, G., Koçak, G., Akçalı, B., İlhan, T., \& Duman, M. (2020). Evaluation of Posidonia oceanica Map Generated by Sentinel-2 Image: Gülbahçe Bay Test Site. Turkish Journal of Fisheries and Aquatic Sciences, 20, 571-581. http://doi.org/10.4194/1303-2712-v20_7_07 